\title{
Assessment of Pentraxin 3 (PTX3) and Sclerostin (SOST) Levels in Serum of Patients with Chronic Kidney Disease
}

\author{
Wijdan Rajh Hamza Al-Kraity
}

Ph.D. in Medical Physiology, Department Medical Laboratories Techniques, Al-Toosi University College

\begin{abstract}
In the present study, 70 of patients were 35 males and 35 females were suffering from chronic kidney disease, and 20 of control group. The samples were collected from Specialized Center for Diseases and Kidney Transplant in AL-Sadder Medical City/Najaf Governorate/Iraq, during the period from July till August, 2019. The ages of control and patients ranged 30 to $69 \mathrm{y}$ old. The patients group was divided into subgroup according to the age and gender, Patients without a complete medical record were excluded and those with other diseases were excluded.

The present study revealed a significant enhance $(\mathrm{p}<0.05)$ inserum PTX3 and SOST levels in CKD compare with control group, while a significant decline $(\mathrm{P}<0.05)$ in serum HDL level of CKD in comparison with control group. The result indicated no significant differences $(\mathrm{p}>0.05)$ in serum of PTX3 and SOST levels between female and males groups of CLD patients. Also, The results showed a significant increase ( $>0.05)$ in serum PTX3 and SOST levels there was a significant increase $(\mathrm{p}<0.05)$ among different groups ages. There is a positive association between PTX3 and SOST concentrations of CKD patients
\end{abstract}

Conclusion: The current study conducted that PTX3 and SOST levels were good markers for diagnosis and detection of chronic kidney disease in both genders the males and females.

Keywords: Chronic Kidney disease (CKD), Pentraxin 3 (PTX3) and Sclerostin (SOST).

\section{Introduction}

The chronic kidney disease (CKD) is refer to along term loss function of kidney, Its identified via the presence of an abnormality of kidney function or structure or both for at least three months ${ }^{\mathbf{1 , 2}}$. The inflammation is might to assume an important role in both atherogenesis and advancement of chronic kidney disease ${ }^{3,4}$.

Pentraxins (PTXs) a superfamily of evolutionarily conserved proteins characterize via acyclic multimeric structure $^{5}$. The Pentraxin-3 (PTX3) is protein encoded by PTX3 gene and produced via avariety of cells and tissues, and especially via innate-immunity cells in responses to

\section{Corresponding Author:}

Wijdan Rajh Hamza Al-Kraity

Ph.D. in Medical Physiology, Department Medical Laboratories Techniques, Al-Toosi University College e-mail: dr.wijdan_rajh@altoosi.edu.iq endothelial cells and proinflammatory signals ${ }^{\mathbf{6}, 7}$. as a consequence of this extra- hepatic synthesis, and also in contrast to C-reactive protein(CRP), the PTX3 levels are thought to be atrue independent marker of disease activity produce at site of the inflammations ${ }^{8}$.

Sclerostin (SOST) is a190 amino acid residue glycoprotein encodevia SOST gene, with a molecular mass of 24 kilo dalton and asequence homology analogous to that of other bone morphogenetic protein antagonist ${ }^{\mathbf{9}, \boldsymbol{0}}$. Sclerostin (SOST) is one of biomarkersas the link between vascular and bone disease ${ }^{11}$. Sclerostin is inhibitors of Wingless Int (Wnt) signaling produced via osteocytes and potentiall play important role in obstruct bone formation ${ }^{\mathbf{1 2}}$. Sclerostin may perhaps affect bone metabolism through chronic kidney disease and the endstage renal undergoing maintenances dialysis ${ }^{13,14,15 .}$

\section{Method and Materials}

Healthy and Patients groups: In the present study, 70 of patients were 35 males and 35 females were 
suffering from chronic kidney disease, and 20 of control group. The samples were collected from Specialized Center for Diseases and Kidney Transplant in ALSadder Medical City/Najaf Governorate/Iraq, during the period from July till August, 2019. The ages of control and patients ranged 30 to $69 \mathrm{y}$ old. The patients group was divided into subgroup according to the age and gender, Patients without a complete medical record were excluded and those with other diseases were excluded.

Blood samples collection: Five $\mathrm{ml}$ of venous blood was acquired by antecubital venipuncture utilizing needle drained from CKD and control subjects between 8:30- 10 AM following 12 hour fasting. The blood was permitted to clot in plain test tube at room temperature. The serum was suctioned after centrifugation at 3000rpm for $10 \mathrm{~min}$, divided into aliquots in epindroff tubes and stored at $-20^{\circ} \mathrm{c}$.

Determination of serum Pentraxin3 (PTX3) level: Human Pentraxin3 Elisa kit (PTX3) was supplied via Bioassay technology laboratoryCo., Ltd. A Catalog
No: E1938Hu .

Determination of serum Sclerostin (SOST) level: Human sclerostin Elisa kit (SOST) was supplied viaBioassay technology laboratoryCo., Ltd. A Catalog No: E3068Hu

Statistical analysis: The data of present study were articulated as (Mean \pm Standard Error), the statistical analysis (Descriptive statistics, Correlation coefficients, P-value) were calculated by using Graphpad prism. The comparison between two groups were analyzed by t-test and the comparison among subdivided groups were analyzed by one-way ANOVA. when P-value $<0.05$ was statistically a significant.

\section{Results}

Evaluation of serum level Pentraxin 3 and sclerostin: The result in figure (1) and (2) exhibit a significant increased $(\mathrm{p}<0.05)$ in serum levels of pentraxin 3 and sclerostin in CKD group compared with in HT group.

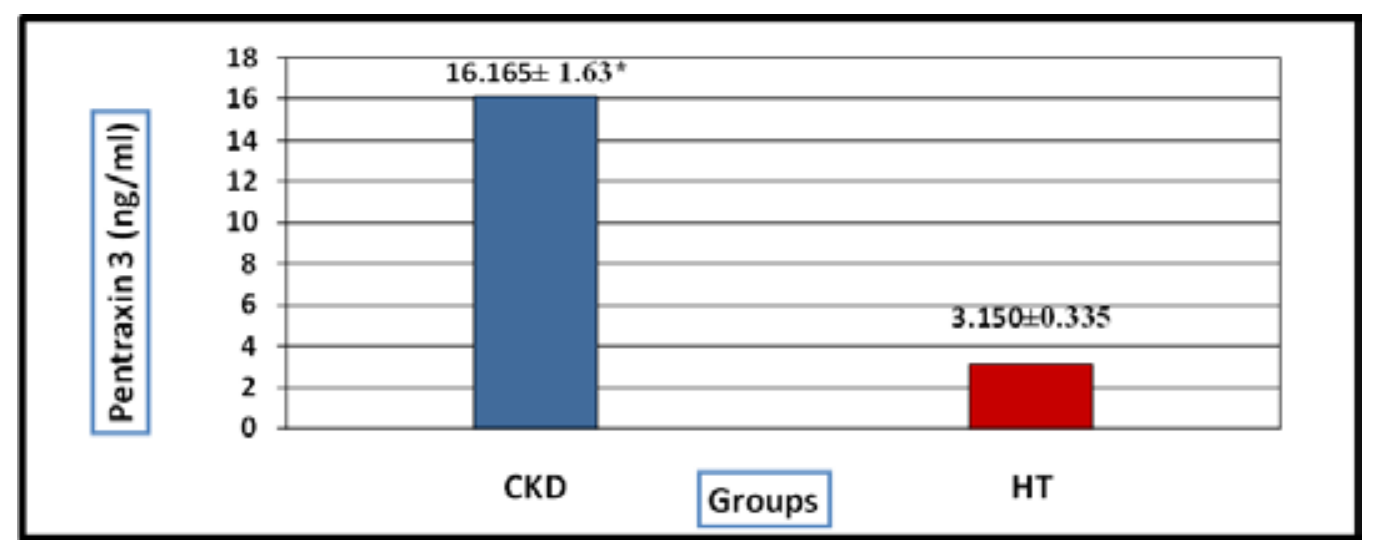

$(*)$ :Statistically significant differences $(\mathrm{p}<0.05)$.

Fig (1): Serum level of Pentraxin 3 between chronic kidney disease Patients and control groups.



(*) :Statistically significant differences $(\mathrm{p}<0.05)$.

Fig (2): Serum level of Sclerostin between chronic kidney disease patients and control groups. 
Evaluation of serum levels pentraxin 3 and sclerostin in CKD patients between males and females groups: In Table (1), The results of present study revealed there is no significant differences $(p>0.05)$ in of pentraxin 3 and sclerostin levels of CKD between female and males groups.

Evaluation of serum levels pentraxin 3 and sclerostin in CKD patientsat different ages groups: Table (2), The result showed a significant increased $(p<0.05)$ in pentraxin 3 and sclerostin levels of CKD at different ages groups .
Table (1): Comparison of serum levels pentraxin 3 and sclerostin between males and females groups of CKD patients.

\begin{tabular}{|l|c|c|}
\hline \multirow{2}{*}{ Groups Markers } & \multicolumn{2}{|c|}{ Mean \pm S.E. } \\
\cline { 2 - 3 } & Males & Females \\
\hline Pentraxin $3(\mathrm{ng} / \mathrm{ml})$ & $15.163 \pm 0.086$ & $17.32 \pm 0.148 \mathrm{~ns}$ \\
\hline Sclerostin $(\mathrm{pg} / \mathrm{ml})$ & $58.235 \pm 2.316$ & $61.145 \pm 2.913 \mathrm{~ns}$ \\
\hline
\end{tabular}

(NS): Statistically mean no significant differences $(\mathrm{p}>0.05)$.

Table (2): Evaluation of serum levels pentraxin 3 and sclerostin CKD patients at different ages groups .

\begin{tabular}{|l|c|c|c|c|}
\hline \multirow{2}{*}{ Groups Markers } & \multicolumn{4}{|c|}{ Mean \pm S.E. } \\
\cline { 2 - 5 } & $\mathbf{3 0 - 3 9 y}$ & $\mathbf{4 0 - 4 9 y}$ & $\mathbf{5 0 - 5 9 y}$ & $\mathbf{6 0 - 6 9 y}$ \\
\hline Pentraxin $3(\mathrm{ng} / \mathrm{ml})$ & $7.583 \pm 0.516 \mathrm{a}$ & $13.023 \pm 0.871 \mathrm{~b}$ & $18.563 \pm 1.245 \mathrm{c}$ & $25.493 \pm 1.89 \mathrm{~d}$ \\
\hline Sclerostin $(\mathrm{pg} / \mathrm{ml})$ & $40.813 \pm 1.261 \mathrm{a}$ & $53.023 \pm 1.87 \mathrm{~b}$ & $64.613 \pm 2.041 \mathrm{c}$ & $80.313 \pm 2.54 \mathrm{~d}$ \\
\hline
\end{tabular}

The different letters mean significant differences $(\mathrm{P}<0.05)$.

Correlation between serum pentraxin 3 and sclerostin levels: Results of the correlation coefficient between pentraxin 3 and sclerostin concentrations at the chronic kidney disease patients revealed in figure (3):

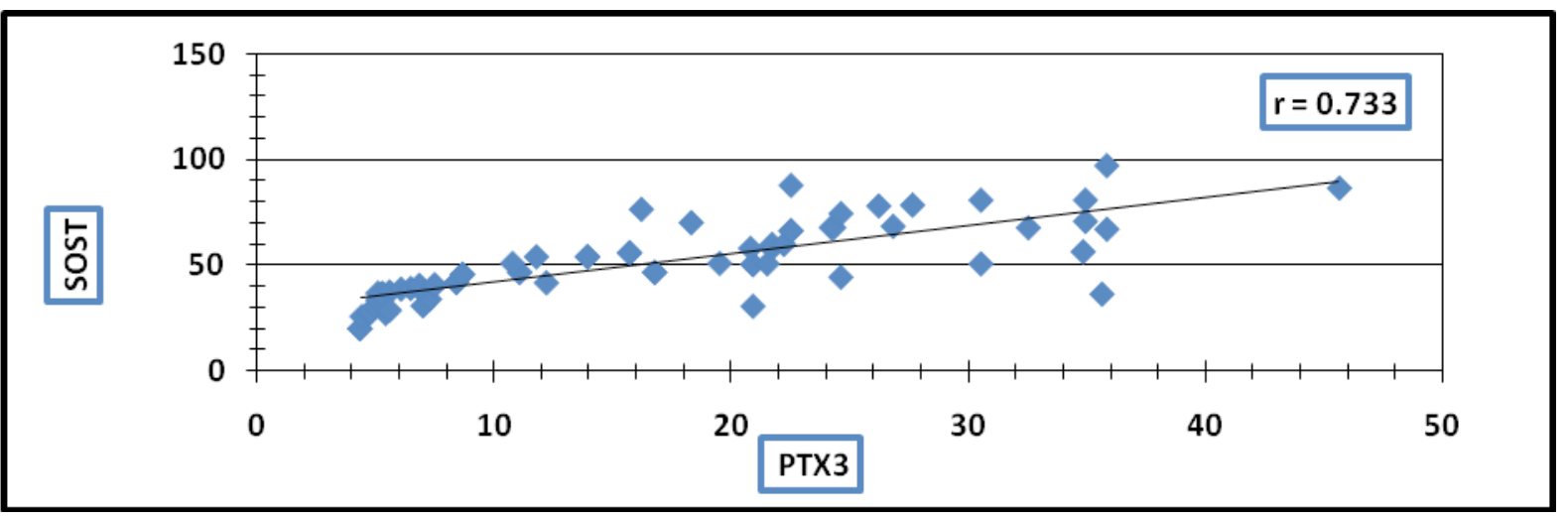

Fig (3): The Correlation between PTX3 and SOST in patients with CKD.

\section{Discussion}

The present study revealed a significant enhanced $(p<0.05)$ in serum level pentraxin 3 and sclerostin in CKD patients in comparison with healthy group. Also the study indicateda positive association between PTX3 and SOST concentrations of CKD patients.

Many studies have confirmed that PTX3 was significantly related with kidney dysfunction and with activity or severity of the inflammatory, autoimmune and cardiovascular diseases ${ }^{\mathbf{1 6}-19}$. The pentraxin3 (PTX3) is "acute phase protein belongs to the same family of
C-reactive protein(CRP)", the inflammatory marker broadly used in clinical laboratories, unlike CRP, the PTX3 rapidly produced at inflamed $\operatorname{sites}^{\mathbf{2 0}}$. Many recent studied confirmed that PTX3 was a sensitive and rapid marker of inflammation in CKD patients ${ }^{21}$. High systemic PTX3 levels were related with increment risk of cardiovascular mortality and morbidity in CKD patients $^{22-24}$. The study of ${ }^{25}$ indicated that PTX3 affect on lipid accumulation promoting uptake of oxLDL via macrophages, supporting aproatherogenic mechanism for the PTX3. Other studies are confirm the actual of the balance between pro and antiatherogenic mechanism 
of PTX3 in progression and development ofthe atherosclerosis in CKD patients, Also PTX3 was shown tobe innate involve in repair and tissue remodeling under an-acidic environment and hypoxiaconditions, which may perhaps support aprotective role of PTX3 through renal damage ${ }^{\mathbf{2 6}}$. The increment in PTX3 levels are related with decrement of Glomerular filtration rate (GFR) and independently predict occurrencethe CKDin elderly women and men, the inflammatory processes are activated in early stages of the CKD and impairment of kidney function ${ }^{24},{ }^{27}$.Thegradual increment of PTX3 associated to the decrment in Glomerular filtration rate may possiblydue to PTX3, is" a large molecular weight substance (molecular weight $40.6 \mathrm{kDa}$ )" characterizevia amultimeric, generally pentameric structure, also be explainvia an "enhanced the release and synthesis and stimulation in the peripheral tissues and decline infunctioning kidney"28.

During the studies that indicated the correlationCKD with MBD and demonstrated that sclerostin (SOST), a glycoprotein derived from osteocyte, the SOSTserve as asoluble inhibitor of Wingless Int(Wnt) signalingpathway and it's have important physiological role to reduced the increment in bone formation, The increment in serum SOST level related with progression of chronic kidney disease ${ }^{29,30}$. These changes are probable explain via changes in creation of SOST in bone ${ }^{31}$ and also explain the changes in kidney function . The research of Fang and et al. ${ }^{32}$ who indicated, that increment in "osteocyticprotein release, vascular osteoblastic-transition and vascular calcification which happen in early phaseof chronic kidney disease. Previous studies indicated a positive correlations between serum SOST and MBD in CKD patients ${ }^{33,34}$. The Mutations in sclerostin structure, especially in SOST gene that encoding of SOST and enhanced Wnt signaling-pathawy which lead to aphenotype characterizevia marked increase in clinical indications and symptoms of bone disease, coinciding with an increase in levels of sclerostin ${ }^{30}$. And enhanced in circulating of SOST have revealed to predict the increment of mortality and decrement of mortality ${ }^{35,36}$.

The bone volume, Mineral density, and bone formation ${ }^{37}$. Many physiological factors that increase the circulating SOST level including men gender and older age ${ }^{38}$. Also the increment of SOST levels were related positively with Body mass index, BMD, and serum uric acid levels But negatively related with total $\mathrm{Kt} / \mathrm{V}$ for urea. ${ }^{38-41}$. Multiple regression analysis in study of ${ }^{\mathbf{3 8}}$ indicated that SOST increment were the associated with other factors including, the GFR, serum calcium and serum phosphorus ${ }^{\mathbf{4 2}}$. Other Studied have indicated that serum SOST increases with ageing ${ }^{\mathbf{3 8}}$, the Ageingis an independent risk factor for vascular disease and chronic kidney disease, And many traditional risk factors for CKD such smoking, diabetes, hypertension, and hyperlipidemia, nontraditional risk factors such as oxidative stress,inflammation, anemia, mineral bone abnormalities $^{43-49}$.

Acknowledgements: I would like express my thanks to all staff of Diseases and Kidney Transplant center and catheterization units at Al-Sadder Teaching Hospital for their cooperation and help, and My thanks and appreciation to the Head of the Department and teaching staff at the Faculty of Medical Laboratories Techniques, Al-Toosi University College .

Ethics Clearance: This article does not contain any studies with human participants directly or animals.

Conflict of Interest: The others declare that there is no conflict of interest

Funding: None, Self-financing source

Data Availability: All data were analyzed during this work are included in the manuscript.

\section{References}

1. NICE Clinical Guidelines. Chronic Kidney Disease: Early Identification and Management of Chronic Kidney Disease in Adults in Primary and Secondary Care. London: National Institute of Health and Care Excellence; 2014.

2. Kidney Disease: Improving Global Outcomes (KDIGO) CKD Work Group. KDIGO 2012. Clinical Practice Guideline for the Evaluation and Management of Chronic Kidney Disease. Kidney International Supplements. 2013;3:1-150.

3. Honda H, Qureshi AR, Axelsson J et al. Obese sarcopenia in patients with end-stage renal disease is associated with inflammation and increased mortality. Am J. Clin. Nutr., 2007; 86: 633-8.

4. Sj€oberg B, Qureshi AR, Heimb€urger O, Stenvinkel P, Lind L, Larsson A, B_ar_any P, €Arnl€ov J. Association between levels of pentraxin 3 and incidence of chronic kidney disease in the elderly. J Intern Med 2015; pp 1-7Gewurz H, Zhang XH, Lint TF: Structure and function of the pentraxins. Curr Opin Immunol., 7: 54-64, 1995. 
5. Breviario F, d'Aniello EM, Golay J, Peri G, Bottazzi B, Bairoch A, Saccone S, Marzella R, Predazzi V, Rocchi M, et al.: Interleukin 1-inducible genes in endothelial cells. Cloning of a new gene related to C-reactive protein and serum amyloid $\mathrm{P}$ component. J Biol Chem.,1992; 267: 22190-22197.

6. Alles VV, Bottazzi B, Peri G, Golay J, Introna M, Mantovani A: Inducible expression of PTX3, a new member of the pentraxin family, in human mononuclear phagocytes. Blood. 1994; 84: 34833493.

7. Mantovani A, Garlanda C, Bottazzi B, Peri G, Doni A, Martinez de la Torre Y, Latini R: The long pentraxin PTX3 in vascular pathology. Vascul. Pharmacol., 45: 326-330, 2006.

8. Fazzini F, Peri G, Doni A, Dell'Antonio G, Dal Cin E, Bozzolo E, D'Auria F, Praderio L, Ciboddo G, Sabbadini MG, Manfredi AA, Mantovani A, Querini PR: PTX3 in small-vessel vasculitides: An independent indicator of disease activity produced at sites of inflammation. Arthritis Rheum, 2001; 44: 2841-2850, 2001.

9. Veverka V, Henry AJ, Slocombe PM, et al. Characterization of the structural features and interactions of sclerostin: molecular insight into a key regulator of Wnt-mediated bone formation. J Biol Chem., 2009;284:10890-10900.

10. Moghazy T, Zaki M, Kandil N, Maharem D, Aly Matrawy K, Moataz Ahmad Zaki \& Alaa Mohamed Ismail El-Banna. Serum sclerostin as a potential biomarker of vascular and valvular types of calcification in chronic kidney disease cases with and without maintenance hemodialysis, Alexandria Journal of Medicine, 2019, 55:1, 15-24.

11. Bruzzese A, Lacquaniti A, Cernaro V and et al . Sclerostin levels in uremic patients: a link between bone and vascular disease. Ren Fail., 2016; 38(5):759-764.

12. Drüeke TB and Lafage-Proust MH. Sclerostin: Just one more player in renal bone disease? Clin J Am SocNephrol., 2011 6: 700-703.

13. Cejka D, Jäger-Lansky A, Kieweg H, Weber M, Bieglmayer C, Haider DG, Diarra D, Patsch JM, Kainberger F, Bohle B, and Haas M. Sclerostin serum levels correlate positively with bone mineral density and microarchitecture in haemodialysis patients. Nephrol Dial Transplant, 2012 27: 226230 .
14. Qureshi AR, Olauson H, Witasp A. and et al. (2015). Increased circulating sclerostin levels in end-stage renal disease predict biopsy-verified vascular medial calcification and coronary artery calcification. Kidney Int; 88: 1356-136.

15. Ketteler M, G. A. Block, P. Evenepoel et al., "Executive summary of the KDIGO Chronic Kidney Disease-Mineral and Bone Disorder (CKDMBD) Guideline Update: what's changed and why it matters," Kidney International, 2017; vol. 92, no. 1, pp. 26-36.

16. Speeckaert M, Speeckaert R, Carrero J, Vanholder R, Delanghe J. Biology of Human Pentraxin 3 (PTX3) in Acute and Chronic Kidney Disease. J Clin Immunol., 2013; 33(5):881-90.

17. Mihai S, Codrici E, Popescu I, Enciu A, Albulescu L, Necula $L$ and et al. Inflammation-Related Mechanisms in Chronic Kidney Disease Prediction, Progression, and Outcome. Journal of Immunology Research, Volume 2018, Article ID 2180373, 16 pages .

18. Hsu H, Lang C, Wang M, Chiang C and Lu K. A Review of Chronic Kidney Disease and the Immune System: A Special Form of Immunosenescence. J Gerontol Geriat Res., 2014, 3:2 .

19. Chena S, Huanga J, Sub H, Yi-Wen Chiua Y, Changa J, Hwanga S, Chena H, Prognostic Cardiovascular Markers in Chronic Kidney Disease. Kidney Blood Press Res., 2018;43:1388-1407.

20. Santos-Silva A, Valente M, Rocha S, Coimbra S, Catarino C, Rocha-Pereira P, Da-Rocha E, Oliveira J, Madureira J, Fernandes J, Sameiro-Faria M, Miranda V, Belo L. Pentraxin 3 in end-stage renal disease: multiple risk biomarker and predictor of all- cause mortality. mediatheque.cyim.com/ mediatheque/media.aspx? mediaId $=64814 \quad \&$ channel $=60398$.

21. Sj€oberg B, Qureshi A, Anderstam B, Alvestrand A, Barany P. Pentraxin 3, a sensitive early marker of hemodialysis-induced inflammation. Blood Purif, 2012; 34: 290-297.

22. Suliman M, Yilmaz M, Carrero J and et al. Novel links between the long pentraxin 3, endothelial dysfunction, and albuminuria in early and advanced chronic kidney disease. Clin J Am Soc Nephrol., 2008; 3: 976-85.

23. Tong M, Carrero J, Qureshi A et al. Plasma pentraxin 3 in patients with chronic kidney disease: 
associations with renal function, protein-energy wasting, cardiovascular disease, and mortality. Clin J Am Soc Nephrol 2007; 2: 889-97.

24. Sj€oberg B, Qureshi AR, Heimb€urger O, Stenvinkel P, Lind L, Larsson A, B_ar_any $\mathrm{P}, €$ Arnl $€$ ov J. Association between levels of pentraxin 3 and incidence of chronic kidney disease in the elderly. J Intern Med., 2016; 279: 173-179.

25. Doni, T. Musso, D. Morone et al., "An acidic microenvironment sets the humoral pattern recognition molecule PTX3 in a tissue repair mode," Journal of Experimental Medicine,2015; vol. 212, no. 6, pp. 905-925.

26. Galvão A, R. Filipe, M. J. Carvalho, J. A. Lopes, M. Amoedo, and G. Silva, Portuguese registry of dialysis and transplantation 2018.

27. Miyaki A, Maeda S, Otsuki T, Ajisaka R. Plasma pentraxin 3 concentration increases in endurancetrained men. Med Sci Sports Exerc., 2011; 43: 127.

28. Bottazzi B, Bastone A, Doni A, Garlanda C, Valentino S, et al. The long pentraxin PTX3 as a link among innate immunity, inflammation, and female fertility. J Leukoc Biol., 2006; 79: 909-912.

29. Fang Y, Ginsberg C, Seifert M et al. CKD-induced wingless/integration1 inhibitors and phosphorus cause the CKD-mineral and bone disorder. J Am Soc Nephrol., 2014; 25: 1760-1773.

30. Kanbay M, Siriopol D, Saglam M et al. Serum sclerostin and adverse outcomes in non-dialyzed chronic kidney disease patients. J Clin Endocrinol Metab., 2014; 99: E1854-E1861.

31. Sabbagh Y, Graciolli FG, O'Brien S et al. Repression of osteocyte $\mathrm{Wnt} / \beta$ - catenin signaling is an early event in the progression of renal osteodystrophy. $\mathrm{J}$ Bone Miner Res., 2012; 27: 1757-1772.

32. Fang $Y$, Ginsberg $C$, Sugatani $T$ et al. Early chronic kidney disease-mineral bone disorder stimulates vascular calcification. Kidney Int., 2014; 85: 142150 .

33. Ishimura E, Okuno $\mathrm{S}$, Ichii $\mathrm{M}$ et al. Relationship between serum sclerostin, bone metabolism markers, and bone mineral density in maintenance hemodialysis patients. J Clin Endocrinol Metab., 2014; 99: 4315-4320.

34. Cejka D, Jäger-Lansky A, Kieweg H et al. Sclerostin serum levels correlate positively with bone mineral density and microarchitecture in haemodialysis patients. Nephrol Dial Transplant, 2012; 27: 226230.

35. Gonçalves F, Elias RM, Dos Reis LM et al. Serum sclerostin is an independent predictor of mortality in hemodialysis patients. BMC Nephrol, 2014; 15: 190.

36. Viaene L, Behets GJ, Claes K et al. Sclerostin: another bone-related protein related to allcause mortality in haemodialysis? Nephrol Dial Transplant, 2013; 28: 3024-3030.

37. Drechsler C, Evenepoel P, Vervloet MG et al. High levels of circulating sclerostin are associated with better cardiovascular survival in incident dialysis patients: results from the NECOSAD study. Nephrol Dial Transpl 2014; 30: 288-293.

38. Canalis E. Wnt signalling in osteoporosis: mechanisms and novel therapeutic approaches. Nat Rev Endocrinol., 2013; 9: 575-583.

39. Mödder UI, Hoey KA, Amin S, et al. Relation of age, gender, and bone mass to circulating sclerostin levels in women and men. J Bone Miner Res., 2011;26:373-379.

40. Kuo T, Lin W, Chao J, Wu A, Chin-Chung and et al. Serum sclerostin levels are positively related to bone mineral density in peritoneal dialysis patients: a cross sectional study. BMC Nephrology, 2019; 20:266.

41. Sharba I and Al-Zahid J. Relationship of Sclerostin with PTH and Erythropoietin in-patient with CKD on dialysis in AL-Najaf Province. International Journal of Advanced Research, 2016; Volume 4, Issue 2, 601-610.

42. Figure $\mathrm{k} A$ and Spasovski $\mathrm{G}$. Is serum sclerostin a marker of atherosclerosis in patients with chronic kidney disease-mineral and bone disorder? Int Urol Nephrol., 2018. https ://doi.org/10.1007/s1125 5-018-1935-5.

43. Kirkpantur A, Balci M, Turkvatan A and et al . Independent association between serum sclerostin levels and carotid artery atherosclerosis in prevalent haemodialysis patients. Clin KidneyJ, 2011; 8(6):737-743.

44. Vlagopoulos PT, Sarnak MJ: Traditional and nontraditional cardiovascular risk factors in chronic kidney disease. Med Clin North Am., 2005; 89: 587-611.

45. Kendrick J, Chonchol MB: Nontraditional risk factors for cardiovascular disease in patients with 
chronic kidney disease. Nat Clin Pract Nephrol., 2008; 4: 672-681.

46. Kanbay M, Vervloet $M$, Cozzolino M, Siriopol D, Covic A, Goldsmith D, et al: Novel faces of fibroblast growth factor 23 (FGF23): iron deficiency, inflammation, insulin resistance, left ventricular hypertrophy, proteinuria and acute kidney injury. Calcif Tissue Int., 2017; 100: 217228.

47. Kanbay M, Solak Y, Siriopol D, Aslan G, Afsar B, Yazici D, and et al. Sclerostin, cardiovascular disease and mortality: a systematic review and meta-analysis. Int Urol Nephrol., 2016; 48: 20292042.

48. Yilmaz MI, Siriopol D, Saglam M, Unal HU, Karaman M, Gezer M, and et al. Osteoprotegerin in chronic kidney disease: associations with vascular damage and cardiovascular events. Calcif Tissue Int., 2016; 99: 121-130.

49. Afsar B, Yilmaz MI, Siriopol D, Unal HU, Saglam M, Karaman M and et al. Thyroid function and cardiovascular events in chronic kidney disease patients. J Nephrol .2017; 30: 235-242. 